\title{
THE INFLUENCE OF MANAGEMENT SUPPORT IN HUMAN RESOURCES COMPETENCIES AND INFORMATION TECHNOLOGY CAPABILITY ON THE EFFECTIVENESS OF INFORMATION SYSTEMS
}

\author{
VERDY MULYANTORO' \\ Malangkucecwara School of Economics \\ Malang, Indonesia \\ E-mail: verdymt@gmail.com \\ DOI: $10.31364 / \mathrm{SCIRJ} / \mathrm{v} 6.18 .2018 . P 0818551$ \\ http://dx.doi.org/10.31364/SCIRJ/v6.i8.2018.P0818551
}

\begin{abstract}
The purpose of this research is to analyze the influence of Management Support In Human Resources and Information Technology On The Effectiveness Of Information Systems. Population and Sample consist This study took the Village Device population in Pandaan District, Pasuruan Regency, East Java with a population of 119 people with details of 10 Village Heads, 10 Village Secretaries, 30 Kaur Desa people and 69 Village Heads.Data were collected through questionnaires and analysis method used is path analysis (path analysis) processed with software Smart Partial Least Square (PLS).Based on the results of parametric calculations, it is known that Management Support has a significant influence on IT Capabilities and Resource Competencies and has a significant effect on the effectiveness of Information Systems. Likewise, IT capabilities and resource competencies have a significant influence on the effectiveness of information systems.
\end{abstract}

Keywords: Management Support, Human Resources and Information Technology, Effectiveness of Information Systems

\section{INTRODUCTION}

The rapidly growing technological era demands all parties who create new breakthroughs and begin to develop new ideas to overcome increasingly fierce competition in the future. All of this can be done if all parties are able to make decisions based on accurate, relevant and timely information. The government as one of the parties that uses information technology is required to be able to make the right decisions based on relevant information. The right decision will provide many benefits for the government in managing its government, one of which is efficiency in government activities. The information system will make it easy for management to produce financial information that is trusted, relevant, timely, understandable and tested so that it helps decision making (Handayani, 2007: 19).
The use of information technology by the government, in this case is the use of computers, can help the process of gathering information more quickly and accurately. However, although in general there are many benefits offered by an information technology, including transaction processing speed and report preparation, calculation accuracy, large data storage, lower processing costs, and multiprocessing capabilities, the implementation of information technology is not cheap ( Nurillah, 2014; Alsharayri, 2012). Especially if the existing information technology is not or has not been able to be utilized optimally, the implementation of technology is useless. These constraints that may be a factor in the use of information technology in government agencies have not been optimal.

Handayani (2010) states that governance as a public sector organization is a driver and facilitator in the success of development, therefore the success of development needs to be supported by the speed of information flow. In addition, the main objective of the government is to improve the welfare of all people. In connection with this the government seeks to realize adequate service to the people. In the government sector, changes in the strategic environment and the advancement of the information system will encourage the government apparatus to improve the performance of the bureaucracy and improve services towards the creation of good governance.

Human resources do have a role in the effectiveness of information systems. However, the role of human resources will not be important if there is no support from management. This was stated by Komara (2004: 65) who gave several reasons for the importance of management support in system development. Among them is that the development of the system is an integrated part of corporate planning which is known to top management therefore development is also required in line with corporate planning, thus supporting the objectives to be achieved by the corporation. Thus, it will be made into making and making decisions in developing a better system.

Research carried out by DeLone\& McLean (1992). The success model of information technology systems 
developed by DeLone\& McLean (1992) uses six factors that can be used as a basis for measuring the success of an information system, namely the quality of information systems (system quality), information quality (information quality), intensity of information system use (system use), end user satisfaction information system (end user satisfaction), individual impact (individual impact), and organizational impact (organizational impact) of the information system. Information technology brings many changes in organizations and business processes.

Based on the explanation above, the researcher can conclude that the information system can be said to be effective if it can achieve its objectives, namely to provide information to its users accurately to support appropriate decision making. Whether or not an information system is effective can be reviewed from the resources and information technology used. The ability of resources in using information systems and the use of information technology in an information system are factors that drive the effectiveness of an information system. This was also what prompted the researcher to conduct research in Pandaan Subdistrict, Pasuruan Regency, East Java. Researchers are interested in knowing how far the effectiveness of the information system is viewed from human resources and information technology. For this reason, the researcher conducted preliminary observations to obtain an overview of the use of information systems by village officials and the information technology used.

In observations made by researchers in early January 2018 until the end of March 2018, the researcher found the fact that the Pandaan sub-district had used an information system in the management of his administration. But unfortunately it is not supported by the competency of the village officials in using the existing information technology so that it has an impact on the lack of adequate information and leads to decisions that tend to be slow. This fact illustrates that the lack of competency of the village apparatus in using the applied technology has an impact on the ineffectiveness of the application of information systems in Pandaan District. Thus, it creates a correlation between human resource management participation and information technology on the effectiveness of information systems.

The description encourages researchers to find out more about the impact of management, human resources and information technology participation on the effectiveness of information systems. This research was conducted to determine the correlation between the participation of human resource management and information technology with the effectiveness of information systems. The benefits that can be obtained from this research are improvements in the quality of human resources in using information technology and information technology improvements that are used and encouraging management to always play a role in the development of information systems so that information systems are effective in achieving their goals, namely providing accurate information in supporting accurate decision making.

\section{THEORITICAL REVIEW}

Management participation systems are conceptualized as executive and management involvement and participation in the field of Information Technology (IT) / Information Systems (. Management support is the involvement of management in implementing information systems and development strategies for information systems that will be implemented. Management's participation in providing support is a guide to the commitment and support for all the resources needed by the company. Igbaria Et al., 1996)

\section{Human Resources}

Adequate technology will not be meaningful if it is not supported by qualified human resources. Human resources are one of the most important factors that cannot even be released from an organization. Human resources are the key that determines the development of the company. In essence, human resources in the form of humans are employed in an organization as a driver to achieve the goals of the organization. Human resources that have adequate potential can increase productivity and operational activities of the company. Baridwan (1998: 7)

\section{Information Technology}

Information technology functions in designing, implementing and maintaining control of the company's operational activities. Information technology has the ability to collect, process and store data, which will later be reported in financial statements. Most organizations increase focus on information technology with high integrity and easier to understand use. Information technology improves accuracy and speed in processing transactions, and provides various benefits in operational efficiency, low costs, and minimizing human error (Abu-Musa, 2008: 34).

\section{Effectiveness of Information Systems}

In general, information systems can be defined as a system in an organization which is a combination of people, facilities, technology, media, procedures and controls aimed at getting important communication lines, processing certain types of routine transactions, giving signals to management and others on important interbal and external events and provide a basis for information for decision making. Information system is a system in an organization that meets daily transaction processing needs that support managerial organizational functions in the activities of an organization's strategy to be able to provide information to certain external parties with the required reports (Sutabri, 2005: 36).

Effectiveness is the ability to choose the right destination or the right equipment for the achievement of a predetermined goal (Handayani, 2007: 3). Organizational effectiveness means whether an organization is able to survive and survive in its larger environment which has the consequence that the survival of the organization will continue to live.

\section{Research Framework}


The research framework is a concept that describes the relationship pattern of all research activities to provide answers to the questions posed in the problem formulation. The research framework used in this research is directed toward the influence ofManagement Support In Human Resources and Information Technology On The Effectiveness Of Information Systems.

Based on the theorized, it can be derived conception and hypothesis model as follows.

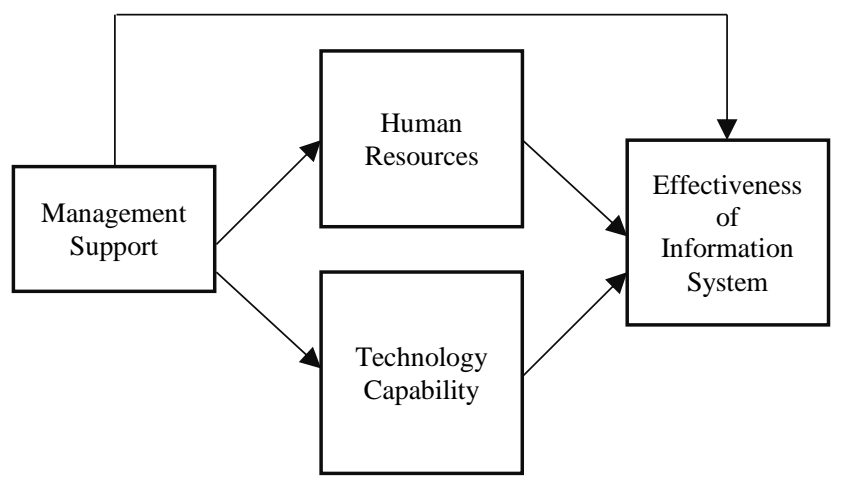

Picture 1. Model of Effectiveness of Information System

\section{Research Hypothesis:}

Based on the above framework, the research hypothesis formulated and tested the truth in this research are:

H1 : management supportinfluence to effectiveness of information systems.

H2 : management support influence to human resources

H3 : management supporti nfluence to capability IT

H5 : effectiveness of information systemsinfluenceto capability IT

\section{RESEARCH METHODOLOGY}

\section{Type of Research}

The research method uses descriptive research with a quantitative approach. In descriptive research, the authors are required to be able to describe or give an explanation about the influence of management support on the competence of human resources and information technology capabilities on the effectiveness of information systems as they are based on existing data and facts. This research was conducted in Pandaan Subdistrict Local Government of Pasuruan Regency. This research lasts for 2 (two) months, starting from April 2018 to May 2018

\section{Method of Colecting Data}

This research is a survey research where the collection tool is a questionnaire. In this research the questionnaires were distributed to the Village Device in Pandaan District, Pasuruan Regency, East Java Pasuruan. The questionnaire is a method to collect primary data by using a set of questionnaires about variables measured through careful planning, arranged and packed in such a way that the answers of all questions can really describe the actual state of variables.

\section{Population and Sample}

This study took the Village Device population in Pandaan District, Pasuruan Regency, East Java with a population of 119 people with details of 10 Village Heads, 10 Village Secretaries, 30 Kaur Desa people and 69 Village Heads. The sample used in this study were 30 people using saturated sampling technique where all members of the population can be used as samples. Thus, using a sample of 30 people can be said to be feasible (Sugiyono, 2007: 36). The sample of 30 respondents will be taken by using the questionnaire.

\section{Research Variable}

Variables in this study include:

a. Independent Variable / Independent Variables

In this research, the variable independent is Management Support (X). The indicators used are developed from Igbaria (1996) as follow : Executing information systems, development strategy and commitment to support all the resources needed by company.

b. Variable Between / Intervening

In this research there are 2 (two) variables that become an intermediate / intervening variable that is:

1) Human Resources (Z1) used the indicators developed from Bodnar (2003) a follows : the use of information technology, user expertise, user involvement, training, top manager support and user conflicts.

2) Technology Capability (Z2) used the indicators are developed from Jarvenpaa and Ives (1991) as follows : the steering committee of information technology development projects, the intensity of active participation related to the use of information technology, the intensity of informal contacts with senior managers in information technology and personal use of technology in daily activities.

c. Dependent Variable / Dependent Variables

In this research, the dependent variable is effectiveness of information system (Y). The indicators used are developed from Sutabri (2005) and Handayani (2007) as follows : combination of people, facilities, technology, media, procedures and controls.

\section{Analysis Method}

In the research toobtain a predefined category assessment, the respondents are arranged into a tabulation of data which is then processed and presented in a tabulation of the frequency distribution. In addition, it would be analyzed using partial 
least square / PLS program. Tabulation data is used to describe and to interpret responses from respondents to each variable. Then to get the result of how big influence of Management Support In Human Resources and Information Technology On The Effectiveness Of Information Systems. , can be done calculation or data processing by using partial least square / PLS program.

\section{RESEARCH RESULT AND DISCUSSION}

Except Indicators DM8, KSD4, and KTI6 are dropped from the model because the indicator value is below 0.70. But according to Ghozali (2015) that the value of outer loading 0.5 can still be tolerated to be included in the model that is still under development. With reference to Ghozali (2015), all indicators are included in the model, because the model used in this study is still a development model.Reliability indicator research test was measured from the Cronbach alpha value. From the results of the data processing, it is known that the Cronbach alpha value has exceeded 0.7. Thus, the research indicator has good reliability.

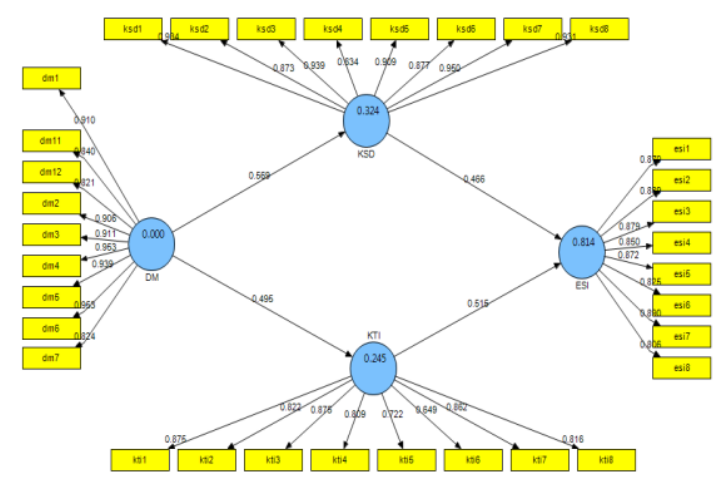

Picture 2. Test Reliabilitas Research Indicators

Tabel 4.

These results indicate that the research model tested has a good goodness of fit test.

\begin{tabular}{|c|r|r|r|r|r|r|r|}
\hline & $\begin{array}{c}\text { Origi } \\
\text { nal } \\
\text { Samp } \\
\text { le (O) }\end{array}$ & $\begin{array}{c}\text { Sample } \\
\text { Mean } \\
(\mathrm{M})\end{array}$ & $\begin{array}{c}\text { Stand } \\
\text { ard } \\
\text { Devia } \\
\text { tion } \\
(\mathrm{STD} \\
\text { EV })\end{array}$ & $\begin{array}{c}\text { Standar } \\
\text { d Error } \\
(\text { STERR } \\
)\end{array}$ & $\begin{array}{c}\text { T } \\
\text { Statistic } \\
\text { s } \\
(\mid \mathrm{O} / \mathrm{STE} \\
\mathrm{RR} \mid)\end{array}$ & $\begin{array}{c}\text { sig } \\
\mathrm{P}\end{array}$ & \\
& & & & & \\
& & & & & \\
\hline DM -> & 0.298 & 0.27912 & 0.103 & 0.10362 & 2.88318 & 0.0 & Accepted \\
ESI & 768 & 2 & 624 & 4 & 3 & 1 & \\
\hline DM -> & 0.604 & 0.60247 & 0.122 & 0.12291 & 4.91705 & 0.0 & Accepted \\
KSD & 402 & & 919 & 9 & 4 & 0 & \\
\hline DM -> & 0.577 & 0.58620 & 0.119 & 0.11907 & 4.84813 & 0.0 & Accepted \\
KTI & 311 & 5 & 079 & 9 & 1 & 0 & \\
\hline KSD -> & 0.347 & 0.36252 & 0.120 & 0.12042 & 2.88143 & 0.0 & Accepted \\
ESI & 008 & 8 & 429 & 9 & 4 & 1 & \\
\hline KTI -> & 0.422 & 0.42022 & 0.127 & 0.12711 & 3.32547 & 0.0 & Accepted \\
ESI & 709 & 4 & 112 & 2 & 9 & 0 & \\
\hline
\end{tabular}

Hypothesis 1. Effect of Management Support on Information System Effectiveness

The inner model estimation results for the direct influence between Management Support on ESI shows the path coefficient value of 0.298768 , t-statistics of 2.883183 and Sig value of 0.01 . This statistical result proves that there is a positive and significant influence between management support for the effectiveness of information systems. Thus the research hypothesis which states there is a significant influence between management support on the effectiveness of information systems.

\section{Hypothesis 2. Effect of Management Support on Human} Resource Competence

The inner model estimation results for direct influence between management support on HR competency shows the path coefficient value of 0.604402 , t-statistics of 4.917054 and Sig value of 0.00 . This statistical result proves that there is a positive and significant influence between management support for HR competencies. Thus the research hypothesis which states that there is a significant influence between management support for HR competencies can be accepted.

\section{Hypothesis 3. Effect of Management Support on IT} Capabilities

The inner model estimation results for direct influence between management support on IT capability shows the path coefficient value of 0.577311 , t-statistic of 4.4848311 and Sig value of 0.00 . The results of this statistic show that it is proven convincingly there is an influence between management support for IT capabilities. Thus the research hypothesis which states that there is a significant influence between management support on IT capabilities can be accepted

Hypothesis 4. Effect of HR Competency on the Effectiveness of Information Systems

The inner model estimation results for direct influence between HR competency on information system effectiveness shows the path coefficient value of $0.347008, \mathrm{t}$ statistics of 2.881434 and Sig value of 0.01 . This statistical result proves that there is a positive and significant influence between HR competencies and the effectiveness of information systems. Thus the research hypothesis which states that there is a significant influence between $\mathrm{HR}$ competencies on the effectiveness of information systems can be accepted.

Hypothesis 5. Effect of IT Capability on SI Effectiveness

The inner model estimation results for the direct influence between IT capabilities on SI effectiveness shows the path coefficient value of 0.422709 , t-statistics of 3.3254479 and Sig value of 0.00. This statistical result proves that there is a positive and significant influence between IT capabilities and the effectiveness of SI. Thus the research hypothesis which states that there is a significant influence between IT capabilities on the effectiveness of SI can be accepted.

Based on the results of parametric calculations, it is known that Management Support has a significant influence on IT Capabilities and Resource Competencies and has a significant effect on the effectiveness of Information Systems. Likewise, IT capabilities and resource competencies have a significant influence on the effectiveness of information systems.
0.29876

8

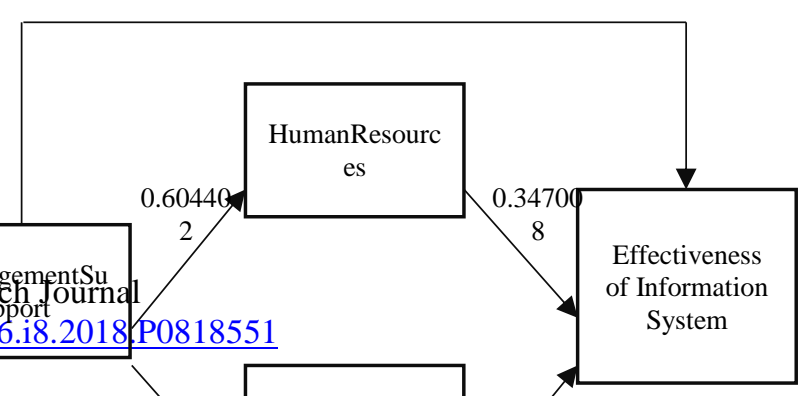


can use at least two sub-districts in Pasuruan district, so that it can be a comparison between one sub-district and another.

\section{REFERENCES}

[1]. Abu-Musa, Ahmad. 2008. Information Technologi And Its Implicantion For Internal Auditing. Managerial Auditing Journal, (Online), Vol.23, No.5, (www.emeraldingsight.com, diakses 15 Maret 2018)

[2]. Alsharayri, M. 2012. Evaluating the Performance of Accounting Information Systems in Jordanian Private Hospitals. Journal of Social Sciences, (Online), 8 (1): 74-78, (http://thesispub.com, diakses 22 Maret 2018).

[3]. Baridwan, Zaki. 1998. Sistem Akuntansi: Penyusunan Prosedur dan Metode. Yogyakarta: BPFE

[4]. DeLone, W.H., and Ephraim R. Mclean. 1992. Information System Success: The Quest for theDependent Variable. Information System Research, March. 6095.

[5]. Elpez, Ivana anda Fink, Dieter. 2006. Information Systems Success in the Public Sector: Stakeholders' Perspectives and Emerging Alignment Model. Informing Science and Information Technology, Vol 3, 229-231.

[6]. Eschenbrenner, Brenda and Nah, Fiona Fui-Hoon (2014), Information Systems User Competency: A Conceptual Foundation. Communications of the Association for Information Systems, Vol. 34, article 81, pp. 1363-1378, June.

[7]. Ghozali, Imam and H. Latan, 2015. Partial Least Squares: Konsep, Teknik dan Aplikasi Menggunakan Smart PLS 3.0, Edisi 2. Universitas Diponegoro

[8]. Handayani, R. 2007. Analisis Faktor-faktor Yang Mempengaruhi Minat Pemanfaatan Sistem Informasi dan Penggunaan Sistem Informasi (Studi Empiris pada Perusahaan Manufaktur di Bursa Efek Jakarta). Jurnal Ekonomi Akuntansi, Fakultas Ekonomi Universitas Kristen Petra, (Online), (http://jurnalakuntansi.petra.ac.id, diakses 24 Maret 2018)

[9]. Igbaria, M., Parasuraman, S., \& Baroudi, J. (1996). "A motivational model of microcomputer usage," Journal of Management Information Systems, 13, 127-143.

[10]. Jarvenpaa, S.L. and Ives B,. 1991. “ Executive Involvement and Participation in the Management of Information Tecnology". MIS Quarterly, Edisi Bulan Juni.

[11]. Komara, Acep. 2004. AnalisisFaktor-Faktor yang Mempengaruhi Kinerja Sistem Akuntansi. Semarang: Universitas Diponegoro.

[12]. Nurillah.2014. Pengaruh Kompetensi Sumber Daya Manusia, Penerapan Sistem Akuntansi Keuangan Daerah, Pemanfaatan Teknologi Informasi, dan Sistem Pengendalian Intern terhadap Kualitas Laporan Keuangan Daerah. Skripsi. 
Semarang: Fakultas Ekonomi dan Bisnis Universitas Diponegoro.

[13]. Sidiq, Ahmad and Astutik, Erni Puji. 2017. Analisis Kapabilitas Teknologi Informasi Terhadap Kinerja Bisnis UKM dengan Orientasi Pelanggan Sebagai Variabel Intervening (Studi Pada UKM Sektor Manufaktur di Wilayah Solo Raya). MEDIA EKONOMI DAN MANAJEMEN Vol. 32 No. 1 Januari 2017. 9-27.
[15]. Sugiyono 2007. Metode Penelitian Bisnis. Cetakan Kesebelas. Bandung. Alfabeta.

[16]. Sutabri, Tata. 2005. Sistem Informasi Manajemen. Andi Offset. Yogyakarta. 